\title{
sciendo
}

\section{CONSIDERATIONS REGARDING THE PROFESSIONAL PRACTICING CHOICE OF THE STUDENTS FROM THE MEDICAL FACULTIES IN ROMANIA}

\author{
SIMONA PÂRVU (BEU) ${ }^{1}$ \\ 1 "Carol Davila" University of Medicine and Pharmacy, Bucharest
}

\begin{abstract}
Keywords: $\quad$ students, medical, migration, disparity, health services

Abstract: Analysing students' options regarding the specialty and the country in which they want to practice, provides useful information in judicious planning of human resources in the health system, the factors that motivate the choice, being both personal, difficult to change, but also economic or social that can be influenced by legislation, so that the number of deficient specialties decreases, and the disparity of the ensuring the medical services in urban to rural areas is reduced. This paper is a qualitative study, with voluntary response, applied to students of public and private medical schools in Romania, that investigates the intention to the professional practicing choice after graduation and the reasons of their decisions. The results show the orientation towards the urban environment in a percentage of $100 \%$ or for migration - between $2.2 \%$ and $50 \%$. Regarding the chosen specialties, the results show that the most frequently chosen specialties were as follows: cardiology, surgery, internal medicine, specialties considered deficient in 2020.(1)
\end{abstract}

\section{INTRODUCTION}

The insufficient human resources in the public health system is a challenge for all health systems in the $21 \mathrm{st}$ century, the estimated deficit for 2030 being 18 million workers. (2)

The migration of the health workforce is a natural consequence of this reality. The phenomenon of migration of health professionals is not fully understood, being encountered in the case of developed countries.

In order to cover the needs of health services for the entire population of a country, the migration of the health workforce from rural to urban areas and to areas with greater economic development must also be taken into account.

The effect of this phenomenon is exacerbating the crisis of health professionals in poor or developing countries from which they are leaving. Although tools have been created at globally level to reduce the negative effects of migration in countries of origin and at the same time respect the freedom of movement of health workers, the Code of Practice adopted in 2010 by the World Health Organization did not have the expected effects, nor globally,(3) either in Romania, but progress has been steady in reducing the negative effects of migration.(4)

\section{AIM}

The aim of the paper is to investigate the professional practicing options for medical students, as well as the factors that contribute to the migration of doctors from the Romanian health system, by analysing the options for insertion on the labour market of students after graduation.

The study also aims to analyse the correlations between legislative changes in 2006-2018 and the migration of the workforce from the health system.

\section{MATERIALS AND METHODS}

The students of the medical universities in Romania represented the target population, and the research stages were: development and validation of an opinion questionnaire with 23 items, in order to survey students' perception of the impact of legislative changes on the quality of health services, as well as their options for the medical specialty and the place where they want to carry out their activity, at the end of their studies;

establishing of the sample characterized by the age, sex, specialties, seniority, level of training; with the help of OpenEpi applications, Version 3, open source computerSSPropor,

collecting of the data through the Google-Form platform using the questionnaire and creating a database with the answers;

statistical processing of the collected data, by introduced in an analysis software (Excel and EpiInfo);

data analysis and presentation of the study results.

The calculated sample based on the total number of 14029 students enrolled at budget and fee places, from the educational offer of 5 public and private university centres, is 374. However, the number of respondents exceeded the estimated sample, being 920 .

\section{RESULTS}

By statistically analysing the students' answers, relevant conclusions were drawn regarding the options for the professional practice. Figure no. 1 represents the preferences of the students, the surgical specialties being in the first place while the deficient specializations are family medicine, oncology or specialities of preventive medicine that are not among the declared intentions.

${ }^{1}$ Corresponding author: Simona Pârvu, Str. Dr. A. Leonte, Nr. 1-3, Sector 5, Cod 050463, Bucureşti, România, E-mail: simona.parvu@insp.gov.ro, Phone: +40724 943392

Article received on 20.12.2020 and accepted for publication on 26.02.2020 


\section{PUBLIC HEALTH AND MANAGEMENT}

Figure no. 1. Structure of respondents by targeted specialties

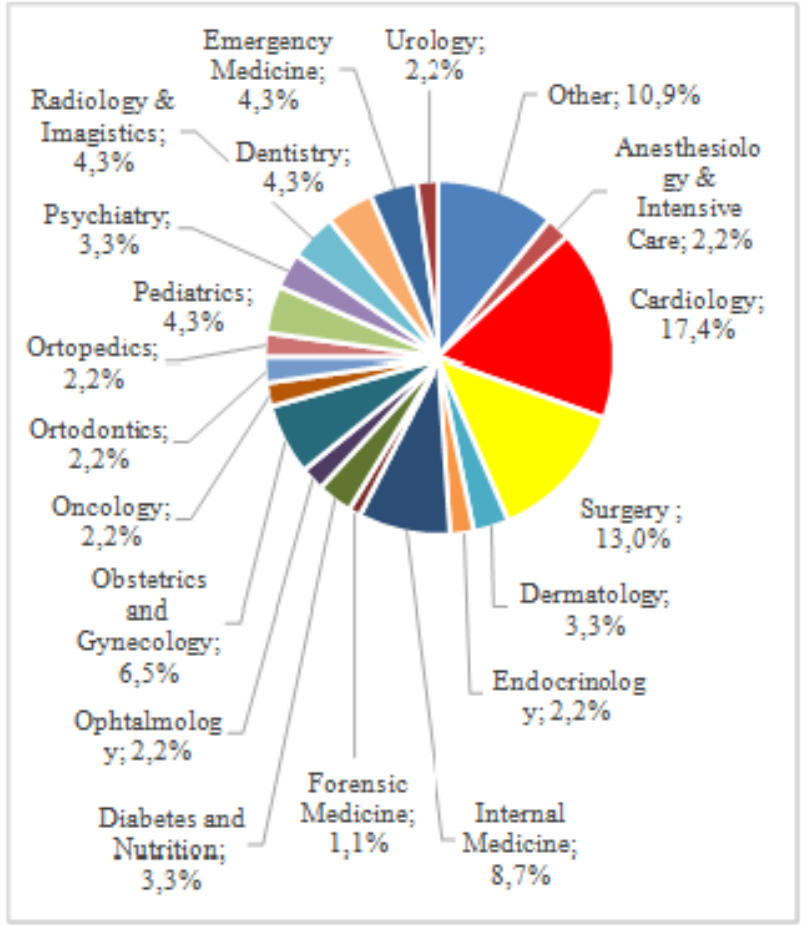

Figure no. 2. The intention to carry out the activity depending on the specialty concerned

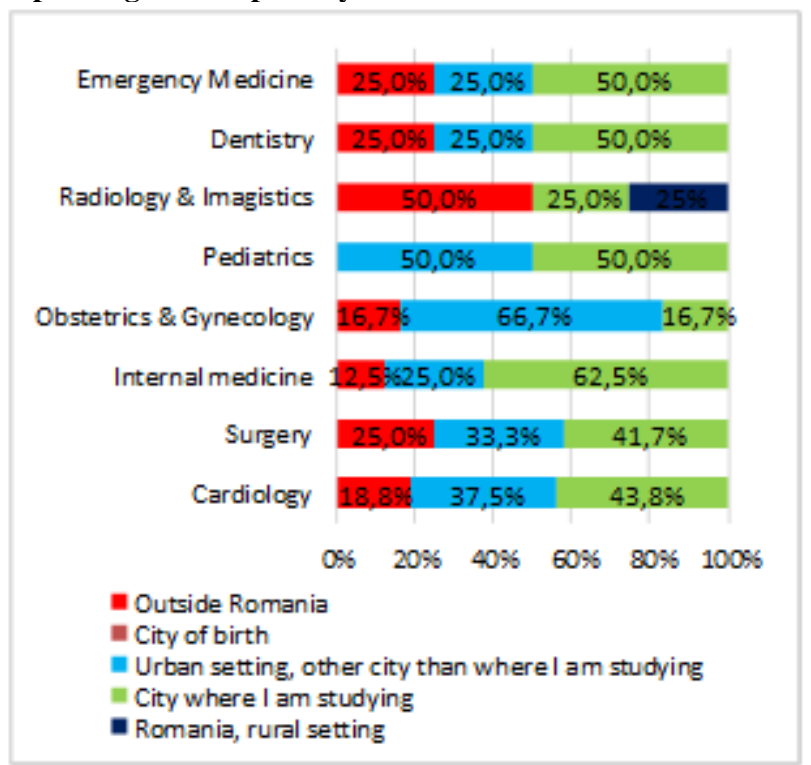

The greatest intention to leave the country is found among students aiming at the specialty of Radiology and/or Imagistics. The slightest intention to leave Romania is found among students who want specialize in internal medicine. Applying the chi-square test, it results that accepting a risk $\mathrm{p}$ $<0.01$, there is a statistically significant difference regarding the intention to carry out the activity depending on the targeted specialty. Another observation that emerges from the analysis of students' responses is the intention to practice in the city where they study, respectively in the university centres, reaching a percentage of $62.5 \%$ in the case of those who choose internal medicine or in another city in a percentage of $25 \%$. Thus, we observe the majority choice to practice in urban areas, accentuating the deficit in terms of providing medical services in rural areas, even if $10.2 \%$ of students come from these areas.
Figure no. 3. Reasons for emigration by specialty

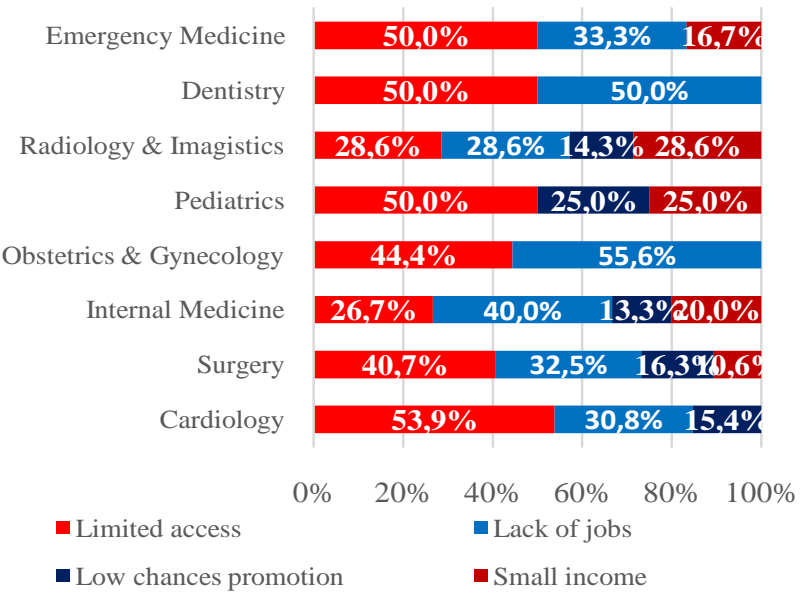

The predominant reason for each specialty is limited access to high performance technology. The second reason invoked is the lack of jobs, for certain specialties, respectively for internal medicine or obstetrics-gynecology.

Figure no. 4. Participation in legislation courses, in total and by student segments

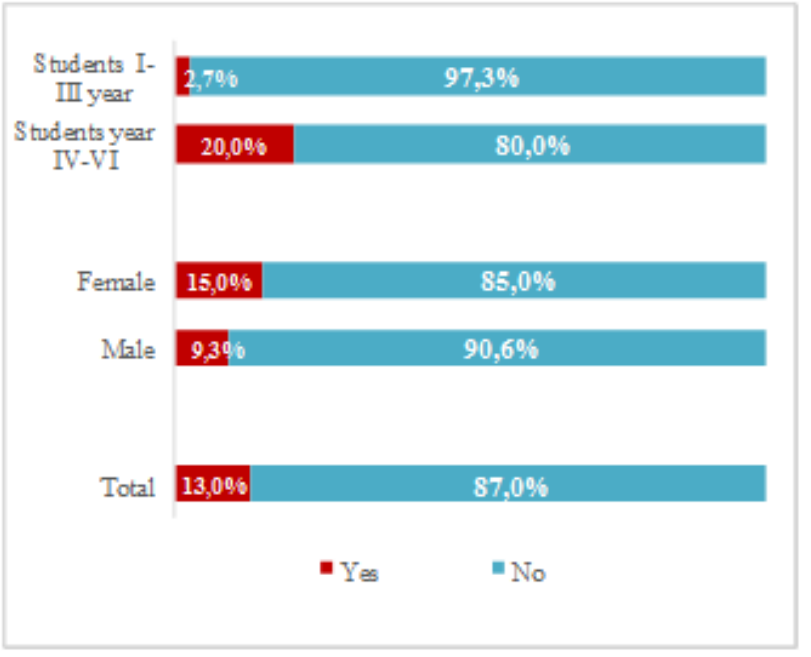

In general, a higher share of courses is found among older students (20\%) and more among female students (15.0\%) than among male students (9.3\%).

Figure no. 5 Participation in legislation courses in the 5 university centres

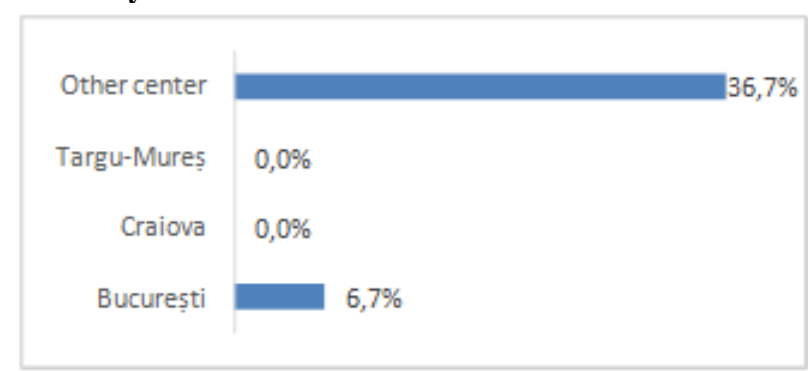

\section{DISCUSSIONS}

Graduates of medical schools enrol in the annual residency exam, joining those who want another specialty or those who did not pass the previous exams. In 2020, 6396 candidates registered for the residency exam (5) for the 4645 


\section{PUBLIC HEALTH AND MANAGEMENT}

places and positions,(6) but 298 places and positions remained vacant, including surgical specialties, emergency medicine or family medicine.(7)

Stimulating the reputation(8) the publication of information on doctors' incomes, but also the free movement of professionals with the recognition of diplomas in the European Union have intensified migration to developed countries.

The intention of Romanian students to migrate after graduation was recorded in national(9) and international studies,(10) but the phenomenon of migration of the health workforce is a global one, and discussions on the effectiveness of this migration must be discussed both from the perspective of the country of destination and from the perspective of the source country.(11)

For the countries where the health professionals migrate, analysing at European level the effects of migration, it was found that the problem of human resources is not solved: the health workforce migration is random, based mainly on the personal projection of the professional career, without a real coverage of deficiencies in the country of destination, the mobility does not take into account the design of human resources made by the system in which the migrant is inserted, and the tendency to change jobs is significantly higher among migrants. Some countries condition access to the labour market by filling jobs in poor areas, such as Germany, but this policy is not the rule. Thus, we can speak of a moderate impact of migration on the real coverage of labour needs in the health services sector in the destination country. $(12,13)$

For the source country, migration has the effect of exacerbating the deficit for certain areas or for certain specialties that overloads the remaining professionals.(14) The beneficial effects on the source health system in the case of temporary mobility, in the case of those working for short periods abroad or of those returning to the system should also be noted. This transfers good practices through professionals and creates links between health units in different systems.

The causes of migration are multiple and not only related to economic aspects. The respondents in the present study indicated as main reasons: limited access to technology, reduced chances of promotion or lack of jobs. These motivations are also found in other national and international studies. It should be noted that personal migration is also common in developed countries, with most European countries being both source and migrating countries. In developed countries, a negative correlation was observed between job satisfaction and the desire to migrate.(15)

The same negative correlation was found between the perceived quality of medical services provided by a health system indirectly influences the decision to leave the system by medical staff.(16)

It was recently found that they returned to the country from which they migrated, possibly due to the improvement of the conditions in the country of origin, but also due to the lack of integration on the labour market. The phenomenon of reverse migration was found both in Romania and in Spain or Finland.

Another result of this research is the intention of students to practice in university centres or in urban areas. The disparity of service provision in urban areas compared to rural areas is a finding in many health systems.(17) Primary health care is among the poorest services in more and more rural areas. A recent study showed that in 2020, 328 rural localities that do not have a family doctor were reported, but also 271 urban localities with a surplus of family doctors.(18) Possible solutions to reduce the gap, can be specially created programmes to attract family doctors in rural areas,(19) creating connections between rural communities and educational units(20) or conducting internships in rural areas during training.(21) Directed and sustained efforts can lead to a good integration of young doctors in rural areas.(22)

The legislative framework from 2006-2018 led in certain periods to the acceleration of the migration of medical staff. Thus, with Romania's entry into the European Union, most of the medical specializations were recognized, and new geographical horizons were opened for practitioners to practice. In 2010, after 67 hospitals were closed by reorganizing beds and reducing the number of beds nationwide, some doctors were again encouraged to practice abroad in the absence of coherent retention policies. Another major legislative factor that has contributed to the migration of doctors is the chronic underfunding of the system, with the blocking of employment in the health system (23) initially for 2010, then with employment in the system for 7 vacancies position - one put up for competition in 2011(24) or for 3 vacancies, one put up for competition between 2011-2019. This policy on securing human resources in the budget system, including the health system, has had the effect of migrating labour force abroad or in the private health system and exacerbating the human resource crisis in the public system by increasing the burden on remaining doctors. The negative impact on the health of the population came as a natural consequence.

Another observed phenomenon is the reversal of the pyramid of health services provided, with the decrease of primary health care services and the increase of the number of specialized consultations. The choice by students of the specialties of obstetrics-gynecology, internal medicine, surgery in which to practice comes as an adaptation to the demand for services on the health services market. In urban areas, specialized health care services are accessed directly by patients who have financial resources. In addition, employees of multinational companies benefit from medical service packages that include free specialist consultations.

In order to counteract all these effects, to diminish the migration phenomenon and to fight the urban/rural disparity in the provision of medical services, so that the access to services ensures to the citizens the right guaranteed by the Constitution to take care of their health, energetic measures are required. from socio-economic realities,(25) and the implementation of these measures must be monitored to correct any deficiencies in effect. Addressing the limitation of migration only in financial terms has proved ineffective.(26)

At the global level as well as in the countries of the European Union, there is a real crisis every year, in terms of the number of doctors, of various specialties, which will ensure healthcare at an optimal level according to demographic, socioeconomic characteristics and in particular, of specific morbidity.(27) There are many explanations for this shortfall, and government structures must be concerned to permanently identify these real causes and to take measures to urgently correct factors that may adversely affect the efficiency of health systems in each country, but and as a whole, at European level. In Romania, repeated legislative changes have been based on somewhat different views on reform, without a coherent global vision.(28)

A specific problem of the reforms in the system is the image created by the media and politicians. An IRES survey from 2010 highlights dissatisfaction with the quality and variety of food, comfort and hygiene in the hospital, but most of the interviewees $(77 \%)$ said they were satisfied and very satisfied with the care given. The migration of medical staff, of all professional categories, is a reality of the transition period,(29) and the phenomenon has been the subject of numerous studies, in an attempt to identify not only causes but also solutions for ensuring the human resources necessary for the functioning of the health system.(30) The opinion of the medical staff 


\section{PUBLIC HEALTH AND MANAGEMENT}

regarding the changes in the system and the impact on the quality of the medical act has been the subject of extensive studies, some even targeting the sphere of national security.(31)

Another study,(32) conducted in 2016 by the deans of medical schools in Romania and Chișinău, analysed broad aspects of the medical system, such as human resources, patient satisfaction, physician satisfaction, resident physicians and knowledge of medical students, on the legislation in domain. The general conclusion of the study shows how necessary is the involvement of universities in collaboration with decision makers, but also with local authorities, to solve pressing problems in the field. The inclusion of health legislation courses in the curricula of some of the medical faculties and the participation of students in these courses is beneficial for the correct information, but the percentage of students who participated in these courses is reduced.(33)

\section{CONCLUSIONS}

The intention to study abroad is an option for most students from medical schools in Romania, even when they choose specialties considered deficient such as cardiology, internal medicine or anesthesia-intensive care. The reasons invoked are related to the limited access to state-of-the-art technology, but also to the lack of jobs.

The students' knowledge regarding the health legislation, as well as the way of informing on this subject is reflected in the choice of the specialty they will embrace and, last but not least, in the choice of the state in which after graduating they choose to practice.

From the analysis of the professional practice option, one can observe the choice for the urban areas, especially in university centres, with the accentuation of the disparity between rural and urban

Through curricula that include health legislation courses, medical schools have created the prerequisites for taking social responsibility, but the student participation is low. It is necessary to include these courses in the curricula of all medical schools and to train students to participate in these courses.

In order to counteract the negative effects of these findings in ensuring human resources and implicitly in the health of the population, it is necessary to ensure sufficient funds and the involvement of local authorities to attract doctors to rural areas by collaborating with faculties and students during training.

\section{REFERENCES}

1. Ordinul nr. 1698/2020 privind stabilirea specialităților deficitare pentru care se organizează rezidențiat pe post în spitale clinice cu sectii clinice universitare, institute sau centre medicale clinice în sesiunea 15 noiembrie 2020

2. Scheffler RM, Campbell J, Cometto, G. et al. Forecasting imbalances in the global health labor market and devising policy responses. Hum Resour Health. 2018;16(5). https://doi.org/10.1186/s12960-017-0264-6

3. Taylor AL, Dhillon IS. The WHO Global Code of Practice on the International Recruitment of Health Personnel: the evolution of global health diplomacy; 2011.

4. Siyam A, Zurn P, Rø O, Gedik G, Ronquillo K, Co C, Vaillancourt-Laflamme C, Rosa J, Perfilieva G, Dal Poz M. Monitoring the implementation of the WHO Global Code of Practice on the International Recruitment of Health Personnel. Bulletin of the World Health Organization. 2013;91:816-823. 10.2471/BLT.13.118778.

5. https://rezidentiat.ms.ro/\# accessed on 01.03.2021

6. https://rezidentiat.ms.ro/20201115/20201115-locuri-cusuplimentare.pdf. accessed on 01.03.2021
7. https://rezidentiat.ms.ro/20201115/loc-post-neocupatm27.pdf. accessed on 01.03.2021

8. McLean T. Will reputational incentives stimulate a reversal of the physician brain drain? J Health Serv Res Policy. 2008 Jan;13(1):50-2. doi: 10.1258/jhsrp.2007.007094. PMID: 18325157.

9. Suciu ŞM, Popescu CA, Ciumageanu MD, Buzoianu AD. Physician migration at its roots: a study on the emigration preferences and plans among medical students in Romania. Hum Resour Health. 2017 Jan 19;15(1):6. doi: 10.1186/s12960-017-0181-8. PMID: 28103939; PMCID: PMC5247802.

10. Wismar M, Maier CB, Glinos IA, Dussault G, Figueras J. Health professional mobility and health systems. Evidence from 17 European countries. WHO Regional Office for Europe; 2011.

11. Buchan J. Health worker migration in Europe: assessing the policy options. Eurohealth-London. 2007;13(1):6

12. Delamaire ML, Schweyer FX. Nationally moderate, locally significant: France and health professional mobility from far and near. Health professional mobility and health systems. 2011;17:181-210.

13. Glinos IA. Health professional mobility in the European Union: Exploring the equity and efficiency of free movement, Health Policy. 2015;119(12):1529-1536,ISSN 0168-8510, https://doi.org/10.1016/j.healthpol.2015.08.010.

14. Gouda P, Kitt K, Evans DS, Goggin D, McGrath D, Last J, Hennessy M, Arnett R, O'Flynn S, Dunne F, O'Donovan D. Ireland's medical brain drain: migration intentions of Irish medical students. Hum Resour Health. 2015 Mar 12;13:11. doi: 10.1186/s12960-015-0003-9. PMID: 25889783; PMCID: PMC4363465.

15. Opoku ST, Apenteng BA. Seeking greener pastures? The relationship between career satisfaction and the intention to emigrate: a survey of Ghanaian physicians. International health. 2014;6(3):208-212.

16. Koch P, Zilezinski M, Schulte K, Strametz R, Nienhaus A, Raspe M. How Perceived Quality of Care and Job Satisfaction Are Associated with Intention to Leave the Profession in Young Nurses and Physicians. Int J Environ Res Public Health. 2020 Apr 15;17(8):2714. doi: 10.3390/ijerph17082714. PMID: 32326518; PMCID: PMC7216191.

17. Groenewegen $\mathrm{P}$, Heinemann $\mathrm{S}$, Greß S, Schäfer W. Primary care practice composition in 34 countries, Health Policy. 2015;119(12):1576-1583, ISSN 0168-8510.

18. Petrencic C. Harta accesului cetățenilor români la serviciile de asistență medical primară oferite de cabinetele de medicina familiei, FNPMF - Februarie 2020 http://www.fnpmf.ro/images/harta-MF-2020.pdf pagina consultata la 01.03.2021.

19. Avery DM Jr, Wheat JR, Leeper JD, McKnight JT, Ballard BG, Chen J. Admission factors predicting family medicine specialty choice: a literature review and exploratory study among students in the Rural Medical Scholars Program. J Rural Health. 2012 Spring;28(2):128-36. doi: 10.1111/j.1748-0361.2011.00382.x. Epub 2011 May 25. PMID: 22458313.

20. Henry JA, Edwards BJ, Crotty B. Why do medical graduates choose rural careers? Rural Remote Health. 2009 Jan-Mar;9(1):1083. Epub 2009 Feb 28. PMID: 19257797.

21. Lee YH, Barnard A, Owen C. Initial evaluation of rural programs at the Australian National University: understanding the effects of rural programs on intentions for rural and remote medical practice. Rural Remote Health. 2011;11(2):1602. Epub 2011 May 13. PMID: 
21568620.

22. Doyle C, Isles C, Wilson P. Time to revisit the skills and competencies required to work in rural general hospitals. PLoS One. 2020 Oct 8;15(10):e0240211. doi: 10.1371/journal.pone.0240211. PMID: 33031438; PMCID: PMC7544037.

23. Ordonanța de urgență nr. 34/2009 cu privire la rectificarea bugetară pe anul 2009 și reglementarea unor măsuri financiar-fiscale.

24. Ordonanța nr. 23 din 30 august 2011 privind reglementarea unor măsuri financiar-fiscale.

25. Holmes GM, Fraher EP. Developing Physician Migration Estimates for Workforce Models. Health Serv Res. 2017 Feb;52 Suppl 1(Suppl 1):529-545. doi: 10.1111/14756773.12656. PMID: 28127768; PMCID: PMC5269547.

26. Okeke EN. Do higher salaries lower physician migration? Health policy and planning. 2014;29(5):603-614.

27. OECD/European Observatory on Health Systems and Policies. Romania: Profilul Sănătății în 2017, State of Health in the EU, OECD Publishing, Paris/European Observatory on Health Systems and Policies, Brussels. 2017. http://dx.doi.org/ 10.1787/9789264285392-ro accesat la 20 ianuarie 2019.

28. Ministerul sănătăţii. Sănătate pentru prosperitate 2014 $2014 . \quad \mathrm{http} / / / \mathrm{www} \cdot \mathrm{ms} \cdot \mathrm{ro} / \mathrm{wp}$ content/uploads/2016/10/Anexa-1-Strategia-Nationala-deSanatate-2014-2020.pdf accesat la 15 ianuarie 2019.

29. Cehan I. Migraţia Medicilor Români Şi Etica Recrutării Internaţionale, Revista română de sociologie, serie nouă, Bucureşti. 2013;XXIV(3-4):327-335.

30. Păunică M, Pitulice C, Ștefănescu A. International migration from public health systems. Case of Romania, Amfiteatru Economic. 2017;19(46):742-756.

31. Păun DL, Toma G. Sistemul sanitar din perspectiva securităţii naţionale, Revista univers strategic, Universitatea Crestina "Dimitrie Cantemir". 2013:IV:164172.

32. Raport tehnic proiectul național de responsabilitate socială a facultăților de medicină din România și Republica Moldova Creșterea accesului la asistență medicală de calitate. 2020 http://medicina.ulbsibiu.ro/ro/documente/cercetare\%20proi ecte/raport\%20tehnic_ responsabilitate\%20sociala_22\%20noiembrie\%20\%202017 \%20BT.pdf accesat 10 martie 2020.

33. Parvu S. Sociodemographic Determinants and Students' Perception Regarding Legislative Changes. J Med Life. 2020 Jan-Mar;13(1):16-20. doi: 10.25122/jml-2019-0082. PMID: 32341695; PMCID: PMC717544522/jml-20190082. PMID: 32341695; PMCID: PMC7175445. 